\title{
PHYSICOCHEMICAL ANALYSIS OF GROUNDWATER QUALITY OF VELLIANGADU AREA IN COIMBATORE DISTRICT, TAMILNADU, INDIA
}

\author{
K. Karthik ${ }^{1, *}$, R. Mayildurai ${ }^{1}$, R. Mahalakshmi ${ }^{1}$ and S. Karthikeyan ${ }^{2}$ \\ ${ }^{1}$ Department of Science and Humanities (Chemistry Division), Kumaraguru College of \\ Technology, Coimbatore - 641049, Tamil Nadu, India \\ ${ }^{2}$ Department of Civil Engineering, Kumaraguru College of Technology, \\ Coimbatore - 641 049, Tamil Nadu, India \\ *E-mail : karthik.k.sci@kct.ac.in
}

\begin{abstract}
The global climatic change has its impacts on the water crisis in some areas and Coimbatore is one of the places where the groundwater levels are declining every year. In the recent past, drilling of the bore-wells increased massively in search of water since most of the open wells dried up in Velliangadu area of Coimbatore district. Open well water used to be the primary source of water for irrigation purpose till last decade but more and more bore wells were drilled in search of water up to 1000 feet underground. Since the drilled bore wells were of a minimum of 300 feet and a maximum of above 1000 feet it was quite interesting to analyze the physicochemical properties of groundwater and help the farmers to gain knowledge on water quality parameters. The quality of groundwater in Velliangadu area was analyzed by determining the $\mathrm{pH}$, Hardness, Alkalinity, Total Dissolved Solids, Chloride content and Electrical Conductivity. Since all the parameters were in good agreement with the standard values given by various organizations it is concluded that the groundwater quality of Velliangadu area is good.
\end{abstract}

Keywords: Physicochemical, Groundwater, Velliangadu, Coimbatore, Pollution

@ ( RASĀYAN. All rights reserved

\section{INTRODUCTION}

Water is a naturally circulating resource abundantly available on earth surface. About $97 \%$ of the water is saline in nature and 3\% is fresh water. Less than $1 \%$ of fresh water is trapped as groundwater in the aquifers which are recharged through rainfalls. Confined aquifers are under pressure because of impermeable materials covered just above and below it. The water in these confined aquifers will rise above the top of the aquifer when drilling bore wells. The recharge of confined aquifers is at an outcrop area where the aquifer emerges upon the earth's surface. So that the confined aquifers will become dry, if there is no or less rainfall in the season. In the case of unconfined aquifers, also called the water table, where the water is in atmospheric pressure. These unconfined aquifers are recharged through direct rainfall water and are impacted by the drought conditions sooner than the confined aquifers. Even though the recent global temperature rises to accelerate the hydrological cycle ${ }^{1}$, climate change alters the rainfall patterns which accelerates the floods and droughts all over the world. Ultimately the drought conditions affect the agriculture and the farmers are on the verge of drilling borewells in search of water. Coimbatore, a district in the state of Tamil Nadu constitutes 19 blocks, which includes 481 villages ${ }^{2}$. The ground water levels in 11 out of 19 blocks have been categorized as overexploited and 4 out of 19 blocks have been categorized as critical. Further, it is evident that the fall in groundwater levels continues for a long time. The major problems identified are declining of groundwater ${ }^{3}$ and drying up of shallow wells. Continuous withdrawal of water has led the water table to go down in the district ${ }^{4}$. Velliangadu is a village in the Karamadai block of Coimbatore district where people practices agriculture and agriculturerelated activities. The groundwater table in the area continues to decline over the years due to over-

Rasayan J. Chem., 12(2), 409-414(2019)

http://dx.doi.org/10.31788/RJC.2019.1225005

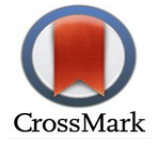


exploitation and excessive withdrawal of water using bore wells. Field visits and interactions with the farmers revealed that drilling of bore wells in search of water in the recent past is very high due to monsoon failures. It is also evident that not all the bore wells are yielding benefits since the failure rate is quite significant. The drilling of bore wells goes beyond a thousand feet in some places due to a decline in groundwater levels. This paper aims to analyze the physicochemical properties of groundwater samples of Velliangadu area of Karamadai block, Coimbatore district, Tamil Nadu, India.

\section{EXPERIMENTAL}

\section{Area of Study}

The physicochemical properties of groundwater samples from seven different places in Velliangadu area have been studied. The groundwater samples were collected between the months of February and April 2018. This period is pre-monsoon in Coimbatore district. The depth of the bore wells is ranged from 250 to 500 feet. The details of the places ${ }^{5}$ where the groundwater samples have been collected is given in Table-1. The Latitude $(\mathrm{N})$ and Longitude $(\mathrm{E})$ of the places were identified using the google maps. In all these areas the water is used to be drinking as well as for agricultural purposes.

Table-1: Location Details of Collected Groundwater Samples

\begin{tabular}{c|c|c|c}
\hline S. No. & Sample Code & Latitude (N) & Longitude (E) \\
\hline 1 & WS1 & $11^{\circ} 12^{\prime} 05^{\prime \prime}$ & $76^{\circ} 49^{\prime} 49^{\prime \prime}$ \\
\hline 2 & WS2 & $11^{\circ} 11^{\prime} 56^{\prime \prime}$ & $76^{\circ} 50^{\prime} 27^{\prime \prime}$ \\
\hline 3 & WS3 & $11^{\circ} 12^{\prime} 20^{\prime \prime}$ & $76^{\circ} 50^{\prime} 16^{\prime \prime}$ \\
\hline 4 & WS4 & $1^{\circ} 12^{\prime} 20^{\prime \prime}$ & $76^{\circ} 49^{\prime} 43^{\prime \prime}$ \\
\hline 5 & WS5 & $1^{\circ} 12^{\prime} 24^{\prime \prime}$ & $76^{\circ} 49^{\prime} 35^{\prime \prime}$ \\
\hline 6 & WS6 & $11^{\circ} 12^{\prime} 17^{\prime \prime}$ & $76^{\circ} 49^{\prime} 35^{\prime \prime}$ \\
\hline 7 & WS7 & $11^{\circ} 12^{\prime} 10^{\prime \prime}$ & $76^{\circ} 49^{\prime} 20^{\prime \prime}$ \\
\hline
\end{tabular}

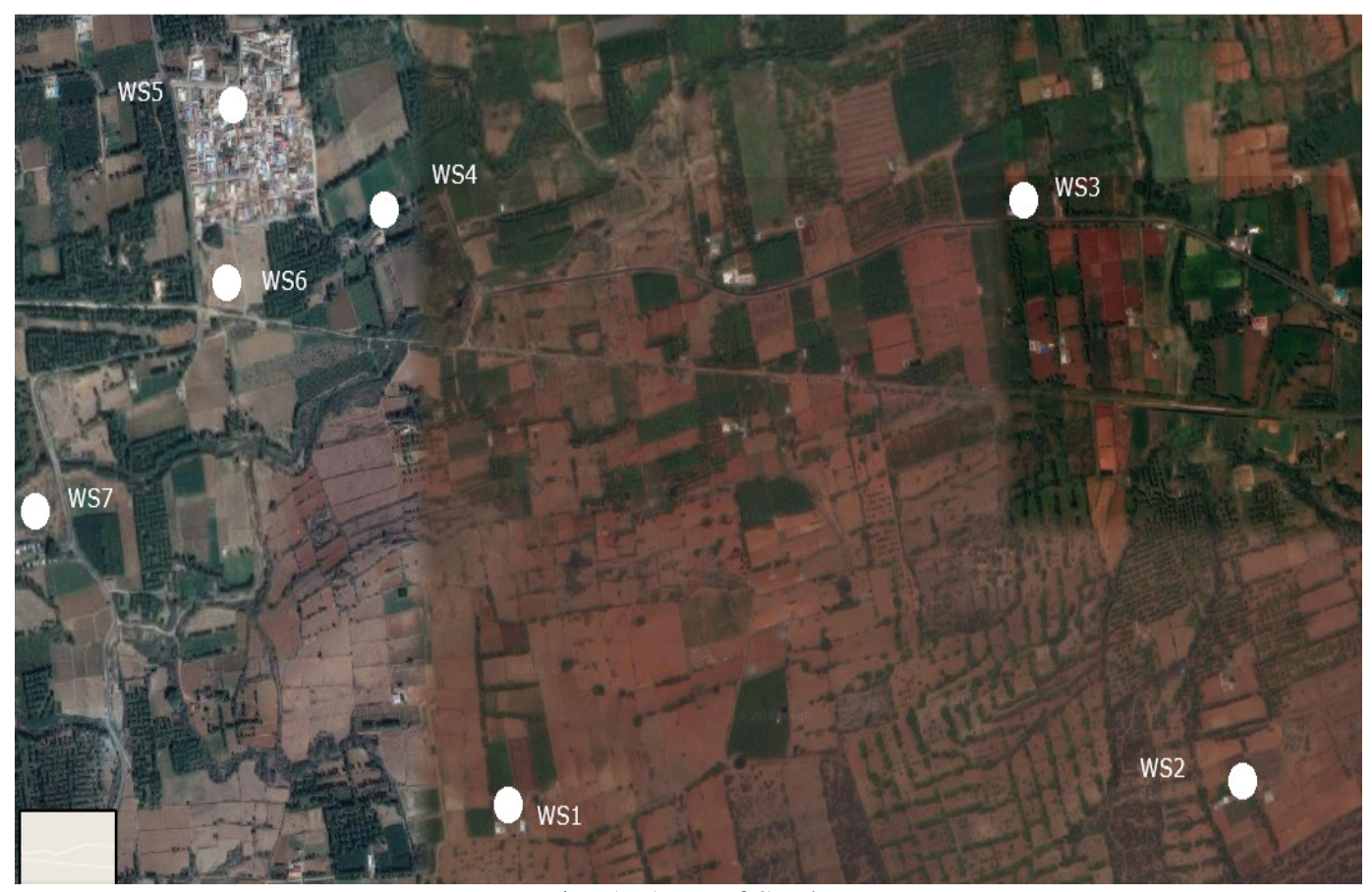

Fig.-1: Area of Study

\section{Sample Collection}

All the groundwater samples have been collected using clean containers. The containers were clearly rinsed before collecting the water samples, tightly closed and labeled after collecting the water samples. The temperature of the water samples has been recorded soon after collecting the water samples. 


\section{Chemical Analysis}

The collected groundwater samples were analyzed for $\mathrm{pH}$, Hardness, Alkalinity, Total Dissolved Solids (TDS), Chloride content and Electrical Conductivity. The standard $\mathrm{pH}$ meter was used to find the $\mathrm{pH}$ of the groundwater samples. The total dissolved solids have been determined using the standard methods given by APHA ${ }^{6}$. Total hardness of the groundwater samples found using EDTA complexometry. Chloride contents were determined using Argentometric method. The electrical conductivity of the water samples has been measured using a standard conductivity meter. The water quality parameters prescribed by various organizations are given in Table- 2 .

Table-2: Drinking water quality parameters

\begin{tabular}{l|c|c|c|c|c|c}
\hline \multirow{2}{*}{ Parameters } & \multicolumn{2}{|c|}{ WHO } & \multicolumn{2}{c|}{ ICMR } & \multicolumn{2}{c}{ BIS } \\
\cline { 2 - 7 } & HDL & MPL & HDL & MPL & HDL & MPL \\
\hline $\mathrm{pH}$ & $7.0-8.5$ & $6.5-9.5$ & $7.0-8.5$ & $6.5-9.2$ & $6.5-8.5$ & - \\
\hline $\mathrm{TDS}, \mathrm{mg} / \mathrm{L}$ & - & - & 500 & 1500 & 500 & 2000 \\
\hline Alkalinity, mg/L & - & 120 & - & - & 200 & 600 \\
\hline $\mathrm{TH}, \mathrm{mg} / \mathrm{L}$ & 200 & 600 & 300 & 600 & 200 & 600 \\
\hline Chloride mg/L & - & 250 & - & 250 & 250 & 1000 \\
\hline EC mS/cm & - & - & - & - & - & - \\
\hline
\end{tabular}

(HDL -Highest Desirable Limit; MPL-Maximum Permissible Limit)

\section{RESULTS AND DISCUSSION}

The analytical data on physicochemical properties of the water samples are reproduced in Table- 3 . The schematic view of various water quality parameters is shown in Fig.-2, 3 and 4.

Table-3: Physicochemical Properties of the Water Samples

\begin{tabular}{l|c|c|c|c|c|c|c}
\hline Parameters & WS1 & WS2 & WS3 & WS4 & WS5 & WS6 & WS7 \\
\hline $\mathrm{pH}$ & 7.4 & 7.6 & 7.4 & 7.6 & 7.5 & 7.7 & 7.3 \\
\hline $\mathrm{TH}, \mathrm{mg} / \mathrm{L}$ & 465 & 511 & 472 & 271 & 269 & 389 & 380 \\
\hline TDS, mg/L & 714 & 678 & 490 & 475 & 608 & 683 & 926 \\
\hline Alkalinity, mg/L & 289 & 295 & 226 & 285 & 333 & 353 & 444 \\
\hline Chloride mg/L & 118 & 102 & 99 & 51 & 83 & 131 & 195 \\
\hline EC mS/cm & 1.49 & 1.37 & 1.04 & 0.99 & 1.21 & 1.37 & 1.90 \\
\hline
\end{tabular}

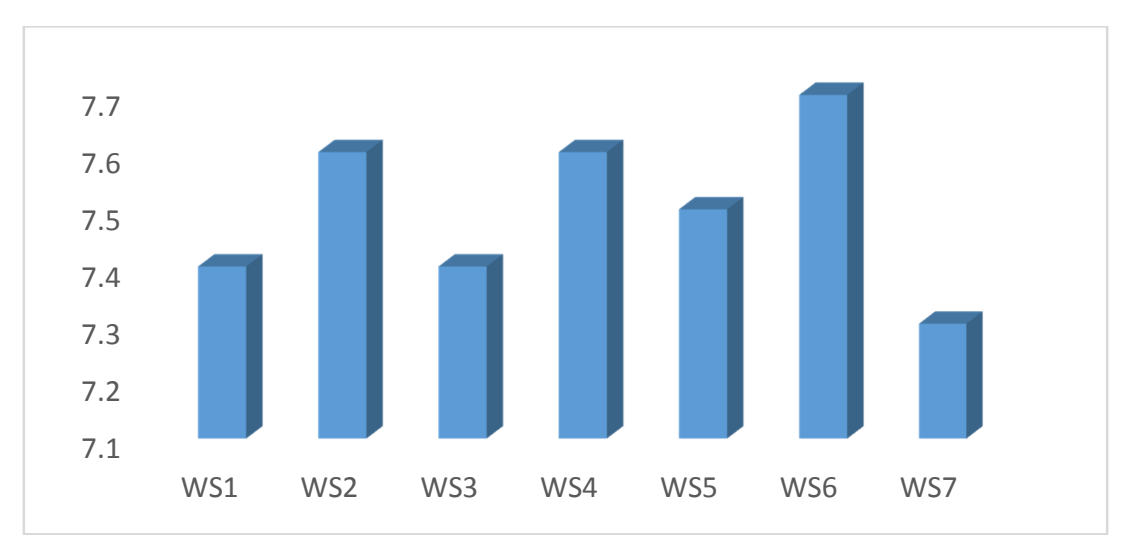

Fig.-2: Graphical View of pH of Water Samples 


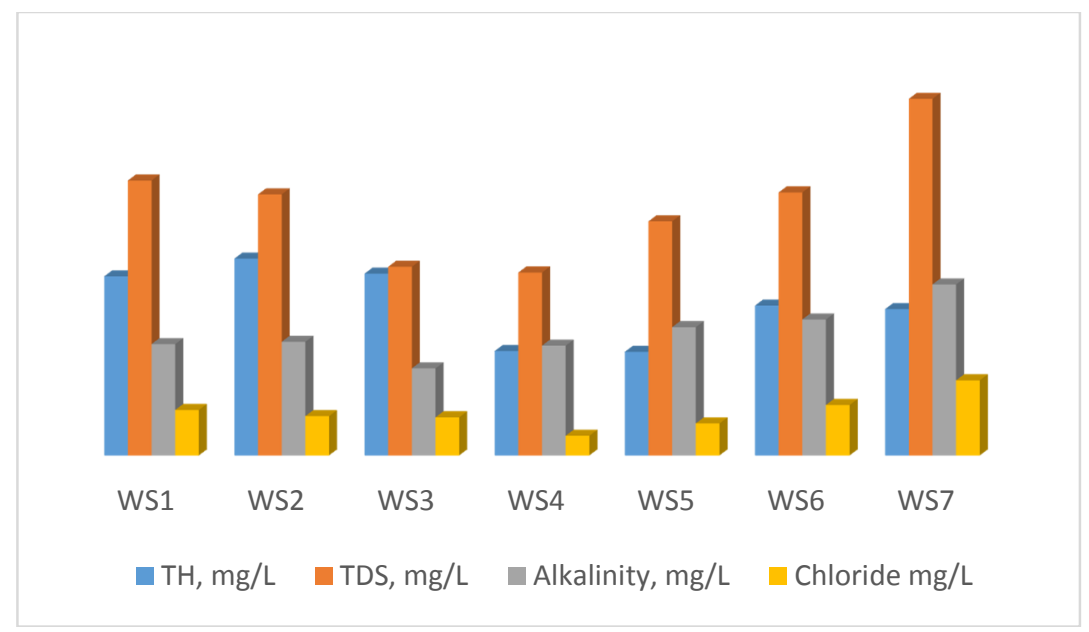

Fig.-3: Comparative View of Total Hardness (TH), Total Dissolved Solids (TDS), Alkalinity and Chloride content in Water Samples

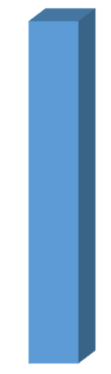

WS1

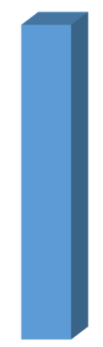

WS2

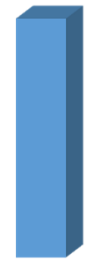

WS3

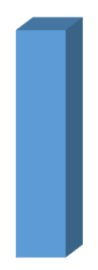

WS4

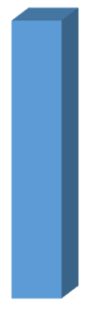

WS5

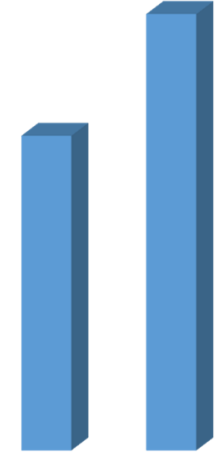

WS7

Fig.-4: Distribution of Electrical Conductivity of Water Samples (WS)

\section{pH}

The $\mathrm{pH}$ of the groundwater samples have been measured using standard $\mathrm{pH}$ meter and found to be in good agreement with the standards prescribed by $\mathrm{WHO}^{7}, \mathrm{BIS}^{8}$, and $\mathrm{ICMR}^{9}$. The $\mathrm{pH}$ of the groundwater samples lies between 7.3 and 7.7 indicates that the underground water in this area is ideal for agricultural as well as domestic purposes. The groundwater sample WS7 measures the lowest and WS6 measures the highest $\mathrm{pH}$ among the water samples collected. Further, the $\mathrm{pH}$ range indicates that the groundwater samples are slightly alkaline in nature.

\section{Total Hardness}

The $\mathrm{Ca} 2+$ and $\mathrm{Mg} 2+$ ions present in the sedimentary rocks and soils causes hardness to the groundwater which flows through it.Very hard water is undesirable for agricultural and drinking purposes. The high amount of calcium and magnesium ions in water results in the formation of hard precipitates also known as scales in the irrigation pipes. Moreover, the calcium and magnesium salts cause problems in the form of sludge as well as scale in drip irrigation tubes which is a serious concern for farmers. Therefore a knowledge on the amount of total hardness present in the groundwater is much needed to plan the irrigation process in a better way. The total hardness of the water samples lies within the limit prescribed by WHO, BIS and ICMR. The highest amount of total hardness, $511 \mathrm{mg} / \mathrm{L}$, is found in the water sample WS2 and followed by WS3, WS1, WS6, WS7, WS4, and WS5. The lowest amount of total hardness, 269 
$\mathrm{mg} / \mathrm{L}$, is found in WS5. The highest amount of total hardness present in WS2 may be from the underground rocks through which the water flows. From the observed values of total hardness of the water samples, it is evident that the groundwater in Velliangadu area is of good quality.

\section{Total Dissolved Solids}

The mean of total dissolved solids in the groundwater samples of Velliangadu is $653 \mathrm{mg} / \mathrm{L} .500 \mathrm{mg} / \mathrm{L}$ and $2000 \mathrm{mg} / \mathrm{L}$ are the desirable and maximum limit prescribed by BIS respectively. Total dissolved solids of the groundwater samples WS4, $475 \mathrm{mg} / \mathrm{L}$ and WS3, $490 \mathrm{mg} / \mathrm{L}$ are below the desirable level. The other water samples were above the desirable level but well below the maximum permissible level prescribed by BIS. The high amount of total dissolved solids may be from the type of soil through which the water flows. From the amount of total dissolved solids determined, it is concluded that the groundwater of Velliangadu area is acceptable for agricultural and drinking purposes.

\section{Total Alkalinity}

The groundwater samples of Velliangadu area has average alkalinity of $318 \mathrm{mg} / \mathrm{L}$ which lies between the desirable and maximum permissible levels prescribed by all the organizations. The highest desirable level as prescribed by BIS is $200 \mathrm{mg} / \mathrm{L}$. The maximum permissible level is $600 \mathrm{mg} / \mathrm{L}$. The highest amount of alkalinity was found in a WS7 water sample, $444 \mathrm{mg} / \mathrm{L}$. The lowest amount of alkalinity was found in a WS3 water sample, $226 \mathrm{mg} / \mathrm{L}$. The alkalinity of water samples measured to give an idea about the salts present in it. The water flows through the soils and sedimentary rocks from which the hydroxide, carbonate and bicarbonates dissolve in it and causes alkalinity. Borates, phosphates are some of the major ionic particles also responsible for alkalinity in water samples ${ }^{10}$. The type of soil and minerals in sedimentary rocks in the Velliangadu area is responsible for the alkalinity of water samples.

\section{Chloride Content}

The determination of chloride content in water samples give an idea about the contamination of water samples viz., by waste water, soluble chloride salts etc. The permissible level prescribed by WHO, BIS and ICMR of chloride water is $250 \mathrm{mg} / \mathrm{L}$, whereas the amount of chloride present in the groundwater samples is between $51 \mathrm{mg} / \mathrm{L}$ and $195 \mathrm{mg} / \mathrm{L}$. The chloride content in all the groundwater samples lies below the permissible limit prescribed by all the organizations. The low levels of chloride revealed that the water samples were free from any waste water pollution and there is no contamination of water by chloride from the minerals rocks or soils. Since the chloride contents are in permissible limits, it is evident that the groundwater is not affected by chloride pollution from industrial or domestic use ${ }^{11}$.

\section{Electrical Conductivity}

The electrical conductivity of groundwater samples lies between $0.99 \mathrm{mS} / \mathrm{cm}$ and $1.90 \mathrm{mS} / \mathrm{cm}$. Among the water samples, WS7 has the highest electrical conductivity and WS4 has the lowest electrical conductivity. Electrical conductivity indicates the presence of free ions in the groundwater samples. The groundwater flows through the aquifers will dissolve the salts present in the soil and rocks which will increase the concentration of ions. The highest electrical conductivity may be due to the high concentration of salts dissolved in it. ${ }^{12}$

\section{CONCLUSION}

The groundwater quality of Velliangadu area is good and on par with the standards prescribed by WHO, BIS and ICMR. The pH of the groundwater lies between 7.3 and 7.7 which is still good for agricultural and domestic purposes. The total hardness ranges from 271 to $511 \mathrm{mg} / \mathrm{L}$ because of the flow of water through the soils and rocks. The total dissolved solids of the water samples measures from 475 to 976 $\mathrm{mg} / \mathrm{L}$ is due to the soil type in the Velliangadu area. Total alkalinity of the water samples lies between 226 and $444 \mathrm{mg} / \mathrm{L}$. The alkalinity of the water samples indicates the possibilities of the presence of hydroxy minerals and carbonate rocks under the ground. The chloride content of the water samples have been measured between 51 and $195 \mathrm{mg} / \mathrm{L}$ which is in good agreement with the permissible levels indicates the groundwater is free from chloride pollution. The electrical conductivity ranges from 0.99 to $1.90 \mathrm{mS} / \mathrm{cm}$, which indicates the presence of free ions. From the water quality parameters determined it is 
concluded that the groundwater samples of Velliangadu area is good and not affected by any water pollution.

\section{REFERENCES}

1. T.G. Huntington, J. Hydrol., 319, 1(2006), DOI: 10.1016/j.jhydrol.2005.07.003

2. District Groundwater Brochure Coimbatore District, Tamil Nadu, Government of India, Ministry of Water Resources, Central Ground Water Board, South Eastern Coastal Region, Chennai. November (2008)

3. Ground water scenario in India pre-monsoon 2017, Central Ground Water Board, Ministry of Water Resources, Govt. of India. (2017)

4. K. Palanisami, A. Vidhyavathi and C. R. Ranganathan, Water Policy, 104(2008), DOI:10.2166/wp.2008.150

5. https://www.google.com/maps

6. APHA, Standard methods for the examination of water and waste water, American Public Health Association, Washington (1989)

7. W.H.O, Guidelines for drinking water quality, Vol.1, Recommendations WHO, Geneva, (1984)

8. IS: 10500 : 2012, Indian Standard Drinking Water- Specification (Second Revision), Bureau of Indian Standards (BIS), New Delhi, India(2015)

9. ICMR. Manual Standards of Quality of Drinking Water Supplies. (1975)

10. M. R. Sharma, Pollut Res., 23, 1(2004)

11. C.E. Renn, Investigating Water Problems, Educational Products Division, LaMotte Chemical Products Company, Maryland (1970)

12. R. Mahalakshmi, P. S. Syedshabudeen and K. Rathina, International Journal of Scientific Research 3, 10(2014), DOI:10.1537/2249555X

[RJC-5005/2018] 